\title{
Adverse Event Seriousness Due to Congenital Anomaly
}

National Cancer Institute

\section{Source}

National Cancer Institute. Adverse Event Seriousness Due to Congenital Anomaly. NCI

Thesaurus. Code C83117.

An indication or description that the seriousness of an adverse event was due to a

congenital abnormality. 